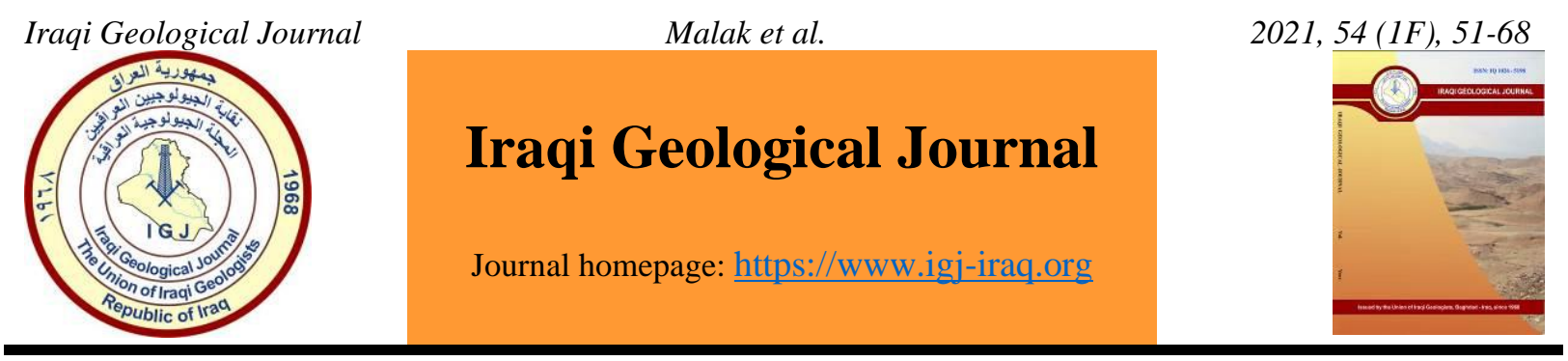

\title{
Stratigraphic and Microfacies Study of Kometan Formation (Upper Turonian-Lower Campanian), in the Dokan area, Northern Iraq
}

\author{
Zaid A. Malak ${ }^{1}$, Omar A. Al-Badrani ${ }^{1{ }^{*}}$ and Rafee I. Al-Hamidi ${ }^{1}$ \\ 1 Department of Geology, College of Science, University of Mosul, Mosul, Iraq \\ * Correspondence: omarbadrani@uomosul.edu.iq
}

Received: 26 February 2021; Accepted: 19 April 2021; Published: 30 June 2021

\begin{abstract}
The Kometan Formation is widely distributed in the northern (Kurdistan region) and central Iraq. The studied area is located near the Dokan Dam, about $58 \mathrm{~km}$., to the Northwest of the Sulaymaniyah city, Northeastern Iraq. The Kometan Formation is exposed on the southwest flank of the Sarah anticline. The formation consists of limestone and dolomitic limestone, which have cherts nodules throughout the formation. The Gulneri Formation is recorded below the Kometan Formation with unconformable contact, while at the top is bounded by the Shiranish Formation unconformably too. Three microfacies are identified, these are lime mudstone, planktic foraminiferal lime wackestone-packstone, keeld planktonic foraminiferal lime wackestone-packstone microfacies. All the sedimentary and fossil evidence refer that the sedimentary environment of the formation is the outer shelf to upper bathyal at the lower and upper parts of formation and its extension to the middle bathyal in the middle part of the formation. Based on the stratigraphic ranges of the recorded Calcareous nannofossils biozones, the age of the Kometan Formation at Dokan area is Late Turonian-Early Campanian.
\end{abstract}

Keywords: Stratigraphy; Microfacies; Kometan; Dokan; Nannofossils; Iraq

\section{Introduction}

The Kometan Formation is widely distributed during the Late Turonian to Early Campanian of northern and central Iraq (Buday, 1980). In addition to its subsurface presence in Qarachoq well no. 1; Demirdagh well no. 29; Kirkuk well no. 116 and Najmah well no. 29 (Jassim et al., 1989). This formation has been described for the first time by Dunnington (1953) in Bellen et al. (1959) in the type section chosen near the villages of Kometan and AinDazah, north of the city of Rania, located in northeastern Iraq. This section is located specifically at the intersection of longitude $\left(44^{\circ} 48^{\prime} 18^{\prime \prime}\right)$ eastward with the latitude ( $\left.36^{\circ} 24^{\prime} 28^{\prime \prime}\right)$ north. According to Bellen et al., 1959, the thickness in the type section is about 36 meters and consists of thinly stratified deposits of light gray chalky limestone. The formation rocks are also affected by the partial silicification process in some of its layers, in the form of chert nodules and sometimes in the form of irregular shapes. Grains of the mineral Glauconite present in some of the lower layers of the formation. Bellen et al. (1959) determined the early Turonian-Santonian age of formation depending on the presence of Gumbelinaspp; Oligostegina; Globotruncana Helvetica Bolli (at base); G.cf. renzi Gandofi; G. sigaliReichel; G. Lapparenti Coronata Bolli; G. Lapparenti bulloides Vogler; G. Lapparenti Brotzen ; G. lapparentitri carinata (Quereau). They also indicated that DOI: 10.46717 /igj.54.1F.6ms-2021-06-26 
the two contact surfaces of the formation: the lower and upper surfaces are unconformable. Researchers' opinions differ on the issue of determining the nature of the lower boundary of the Kometan Formation in northeastern Iraq, depending on the location, and the identity of the formation below it. Dunnington (1953) in Bellen et al. (1959) indicated that the lower contact surface of the Kometan Formation with the Balamo Formation in northeastern Iraq unconformable surface due to the presence of a sedimentary gap between the two formations, and the same unconformable surface is recorded by Ameen and Gharib (2014), it was considered as the equivalent of Pre-Aruma unconformity on the Arabian plate (karim et al., 2008), it was concluded that the contact surface between the Dokan and Kometan formations in the Dokan area is a harmonic surface, due to the absence of the erosional surface and the continuation of sedimentation through the Cenomanian in the Transition Zone that lies between the two Formations. Taha and Karim, (2009) confirmed that the lower contact of the Kometan Formation with the Gulneri Formation in the Dokan area is characterized by the absence of the erosion features, such as corridors or ancient soil features on the upper surface of the Gulneri Formation.

Bellen et al. (1959) indicated that the upper contact surface of the Kometan formation with the Shiranish Formation (Campanian) appeared as an unconformable surface of pebbly sandstone with green glauconite minerals grains. Karim et al. (2008) considered the upper boundary with Shiranish formation as unconformity surfaces and that is indicated by the presence of two highly bioturbated zones, zone of Glauconite and extinction of planktic foraminifera. Ameen and Gharib emphasized such unconformable boundaries in the Dokan area as well as in the Safin area. Jaff et al. (2014) and (2015) also emphasized that unconformity through planktic foraminiferal zonations and the presence of about 2 $\mathrm{m}$ highly bioturbated and glauconitic horizon. Many studies dealt with the determination of the age of formation including Youkhanna, 1976; Abawi and Hammodi, 2005; Al-Khafaf, 2005) which are refered to L.Turonian - E. Campanian age. The study area is located near the Dokan Dam, specifically $58 \mathrm{~km}$ to the Northwest of the city of Sulaymaniyah, Kurdistan region- North-East of Iraq (Fig. 1). The Kometan Formation is exposed on the southwest flank of Sarah's anticline, Specifically at the

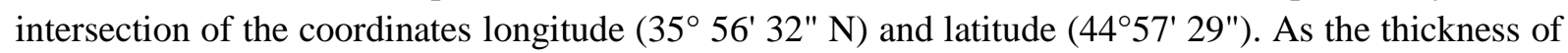
the formation is about 118 meters. The formation consists mainly of well bedded limestone and dolomitic limestone mostly stylolite. The formation contains cherts nodules that are spread in some levels of the formation and near the contact surfaces between the beds. The Qamchoqa Formation is located below the Kometan Formation, and the contact appeared unconformable, while at the top it is bounded by a Shiranish Formation unconformably too. Tectonically, the studied area is located within the high folded thrust zone according to Lawa et al. (2013), Omer et al. (2015) and high folded zone according to Fouad, 2015. The Kometan Formation represents deposited in the lower part of the AP9 tectonostratigraphic Megasequence (Late Cretaceous - Early Palaeogene (92-63 Ma)) (Sharland et al. 2001, Ameen and Gharib 2014). In the Late Cenomanian-Early Turonian period the micro- continents that had split of the Arabian plate in late Tithonian time approached the trench of the intra-oceanic subduction zone (Fig. 1). The onset of growth of N-S trending structures in S Iraq, Kuwait, and Saudi Arabia at this time may have been caused by the diachronous collision of these micro-continents with the fore-arc region above the trench. The onset of deformation of the north-facing passive margin of the southern Neo-Tethys is recorded by the deposition of the conglomeritic unit of the Qulqula group N-E Iraq (Jassim and Goff, 2006). The Kometan Formation was deposited following the period commenced with the onset of the first ophiolite obduction onto the previously passive northeast margin of Arabian plate lead to fault renew and uplift of North-East margin of the Arabian plate (Sharland et al., 2001). Numerous subsequent ophiolite obduction along the northeastern and northern plate margins resulted in the development of a foreland basin (Late Turonian early Campanian) formed around the northern margin of the Arabian Plate in response to loading of the crust by thrust sheets generated as a result of compression (Jassim and Goff, 2006). The Kometan Formation deposited in a foreland basin in the last events of Cretaceous Neo-Tehthyan subduction (Numan, 2001) and it's called Kurdistan foreland basin 
by Lawa 2018, which show progressive shallowing upward. Followed by the closure of Neo-Tethys, uplift of the Zagros fold belt, and rifting and spreading of the Gulf of Aden and the Red Sea. (Sharland et al., 2001). The Khasib, Tanuma, Sa'di, and Kometan formations depict the lower part of the Megasequence AP9 (Jassim and Buday, 2006) (Fig. 2a). The isopach of the late Turonian-Early Cenomanian sequence reveals three depocenters, the first (deep inner shelf and lagoonal facies) of Khasib, Tanuma, Sa'di formations, and the second facies of the Kometan Formation (outer shelf and basinal facies) in the sequence contains two main facies (Fig. 2b).
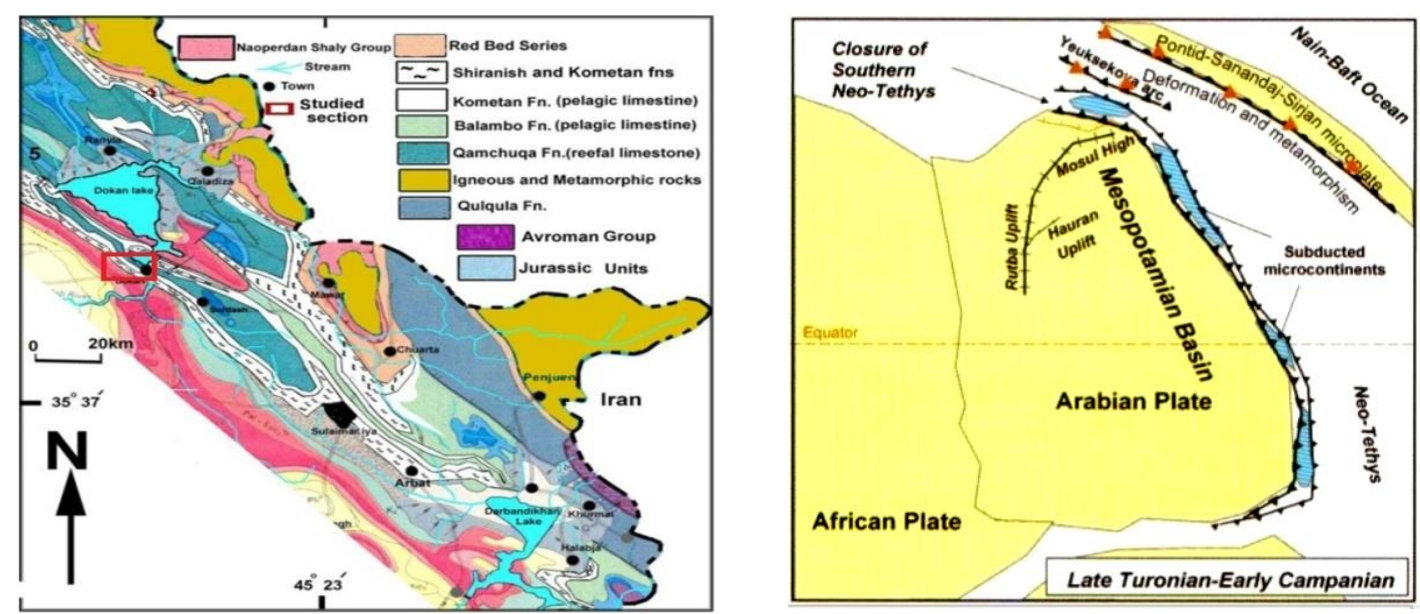

Fig. 1. Location of the studied section (After Sissakian 2000) (Left); Turonian -Early Campanian geodynamic development of the Arabian plate (After Aqrawi et al. 2010)
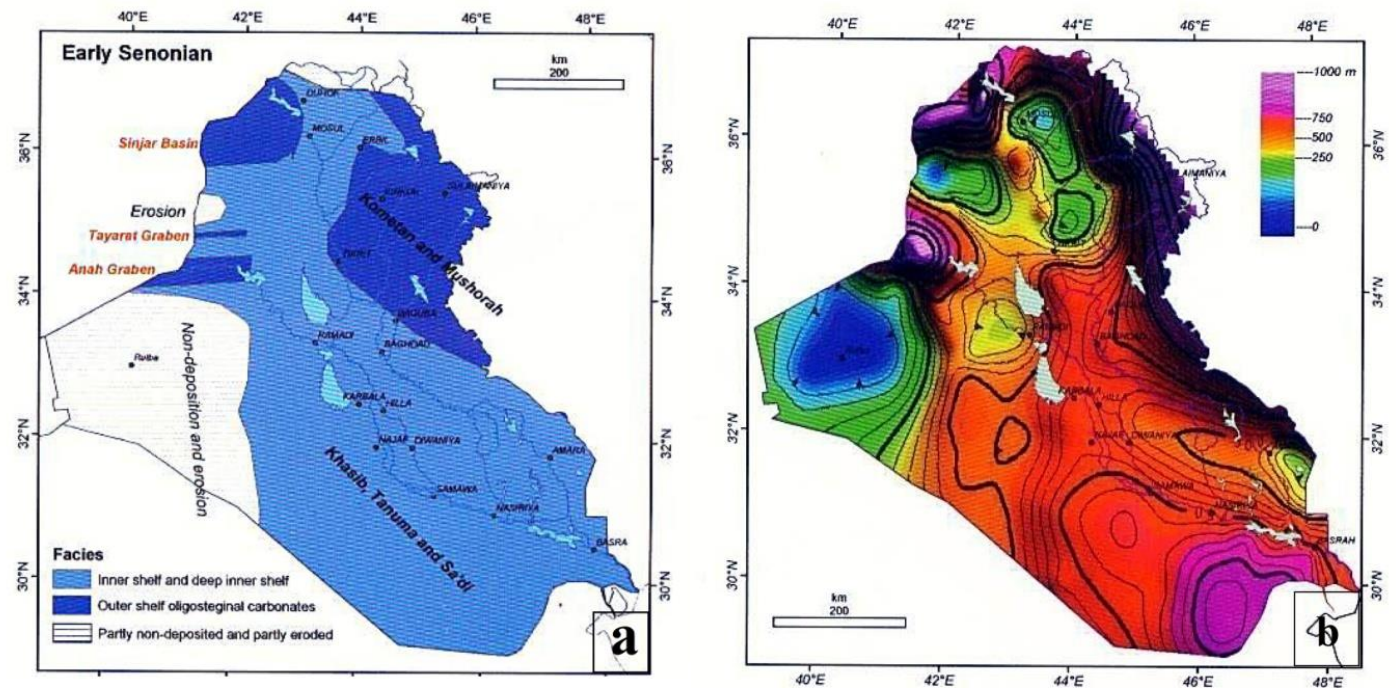

Fig. 2. A) Paleogeographic map of the Early Senonian rock units in Iraq; B) Thickness map of the Late Turonian-Early Campanian sequence (after Jassim and Goff, 2006)

\section{Materials and Methods}

The fieldwork included a description of all field phenomena in the outcrops, including the thickness of the beds, studying the nature of the contact surfaces between them, the toughness, color, and other physical characteristics, as well as following the lateral and vertical changes of the beds and recording all the sedimentary structures that they may contain. Forty rock samples were selected from the Kometan Formation exposed in the Dokan Dam area. These samples are used for the studying of the 
calcareous nannofossils depending on the thin section (under a transmitted-light microscope). The calcareous nannofossils are extracted by using the method (H) (Armstrong and Brasier, 2005). It is an extraction method for microfossils that can be properly examined, when it is extracted from the rocks, each paleontologist tends to have favorite methods for these procedures. The sample preparation the smear slides that provide method for producing slides of calcareous nannofossils by a small amount of the disaggregated sample is placed in distilled water and a drop of a dispersant. The cover slip is left to dry on a warm hot plate. To make permanent mounts allow the slide and residue to dry at a low temperature away from possible sources of contamination. Place a drop of mounting medium (e.g. Canada Balsam) on a clean cover slip and drop this over the residue. Allow to drying before examining with transmitted light. All thin sections were made for rock samples submerged with a solution of the red dye of Alizarin Red (Dickson, 1966 in Carver, 1971) to distinguish between crystals of the mineral calcite, and dolomite, which is not affected by the dye. These thin sections were studied under a polarizing microscope from a petrographic point of view. The diagenetic processes affecting them were determined and the types of microfacies were extracted in order to extrapolate the sedimentary environment of the formation.

\section{Results}

\subsection{Lithostratigraphy}

In general, the Kometan Formation consists of limestone, white to yellowish weathered color and sometimes yellowish in color. In general, the formation is well bedded with the prevalence of stylolite, especially at the contact surfaces between the beds. With the spread of chert nodules in different parts of the formation, which are randomly distributed, but often appear in a horizontal pattern and near the contact surfaces between the beds (Fig. 3). The lower contact surface of the formation with Gulneri Formation is characterized by present of a very thin bed of glauconite (Bellen et al.,1959; Ameen and Gharib, 2014). The lower 60 meters of the Kometan Formation consists of well bedded $(15-35 \mathrm{~cm})$, tough limestone of grayish white colour and free of clastic sediments, This part is characterized by the predominance of Stylolites and joints as well as the presence of pyritic nodules spread randomly in some beds, while the upper parts of this sequence (last 25 meters) are characterized by the appearance of thin beds $(10-15 \mathrm{~cm})$ of the black shale, interbedded between the limestone beds. The appearance of the shale gradually decreases at the end of this sequence with the continued presence of stylolite and chert nodules, which are arranged parallel to the surfaces of the beds. The remaining part of the formation is 48 meters thick and appears as sequences of well-bedded limestone of white to yellowish-white color, this part is characterized by flint knots and the presence of fractures and stylolite surfaces. The upper contact of the formation is unconformable with the overlying Shiranish Formation (well-bedded limestone-marly limestone). The contact is appearing as bioturbation surface (Glossifungites ichnofacies) and Thalassinoides burrows presence at a hard ground surface at the top of Kometan Formation (Karim et al. 2001; Malak, 2015).

\subsection{Microfacies Analysis}

In this study, the microfacies of the Kometan Formation successions were determined, where the nature of these microfacies and their associated foraminifera are important in determining the ancient depositional environment. The Dunham classification of carbonate rocks was relied upon to determine the exact microfacies, and then it was compared with the standard microfacies of the (Flügel, 2004 and Wilson, 1975). Depending on the study and accurate diagnosis of the components of the thin sections, three microfacies has been determined, which is (K.1, K.2, and K.3). Below is a precise explanation of these microfacies: 


\subsubsection{Lime mudstone microfacies (K.1)}

This microfacies was common within the lower part of the Kometan formation. It is composed entirely of micrite. Neomorphism of micrite to microspar and dolomitization were recognized in the section.

\subsubsection{Planktonic foraminiferal lime wackestone- packstone microfacies (K.2)}

This microfacies is considered as the most common among other facies, it occurs in different places within the studied section. The allochems of this microfacies range between 20-65\% in a micritic matrix, consists of globular foraminifera such as Globigerinelloides ultramicara, Heterohelix reussi (Fig. 4 a), Hedbergella planispira, Hedbergella holmedelensis, Whiteinenella archaeocretacea (Fig. $4 \mathrm{~b}$ ) and some pelecypods test. In the diagnosis of some types of planktic foraminifera, we have relied on personal contact with the specialists in the department of Geology/ University of Mosul, and on each of the following references, Loeblich \& Tappan,1984 and Caron, 1985. The microfacies that occur within the upper parts of the formation are characterized by the following types of planktonic foraminifera (Archaeoglobigerin ablowi (Fig. 4c), Archaeoglobigerina cretacea), whose presence indicates rather shallow sedimentary environments. The microfacies was subjected to variable digenetic processes, such as neomorphism, compaction. According to Wilson (1975), the microfacies corresponds to SMF (8) within the FZ (2) of Flügel (2004).

\subsubsection{Keeld Planktonic foraminiferal lime wackestone-packstone microfacies (K.3)}

This microfacies appeared at the middle part of the formation. The skeletal grains consist of keeled planktonic foraminifera, about $20-40 \%$ in a micritic matrix. The presence of species that contain keeled, as Dicarinella primitive (Fig. 4d), Dicarinella imbricata, Dicarinella concavata (Fig. 4e), Dicarinella hagni, Marginotruncana renzi, Marginotruncana sigali, Marginotruncana marginata, Marginotruncana coronata (Fig. 4f)), indicates relatively deep marine environments ( 200-1500m.) within the upper slope. The facies is equivalent to SMF (3) of Wilson (1975) and FZ (1) of Flügel (2004).

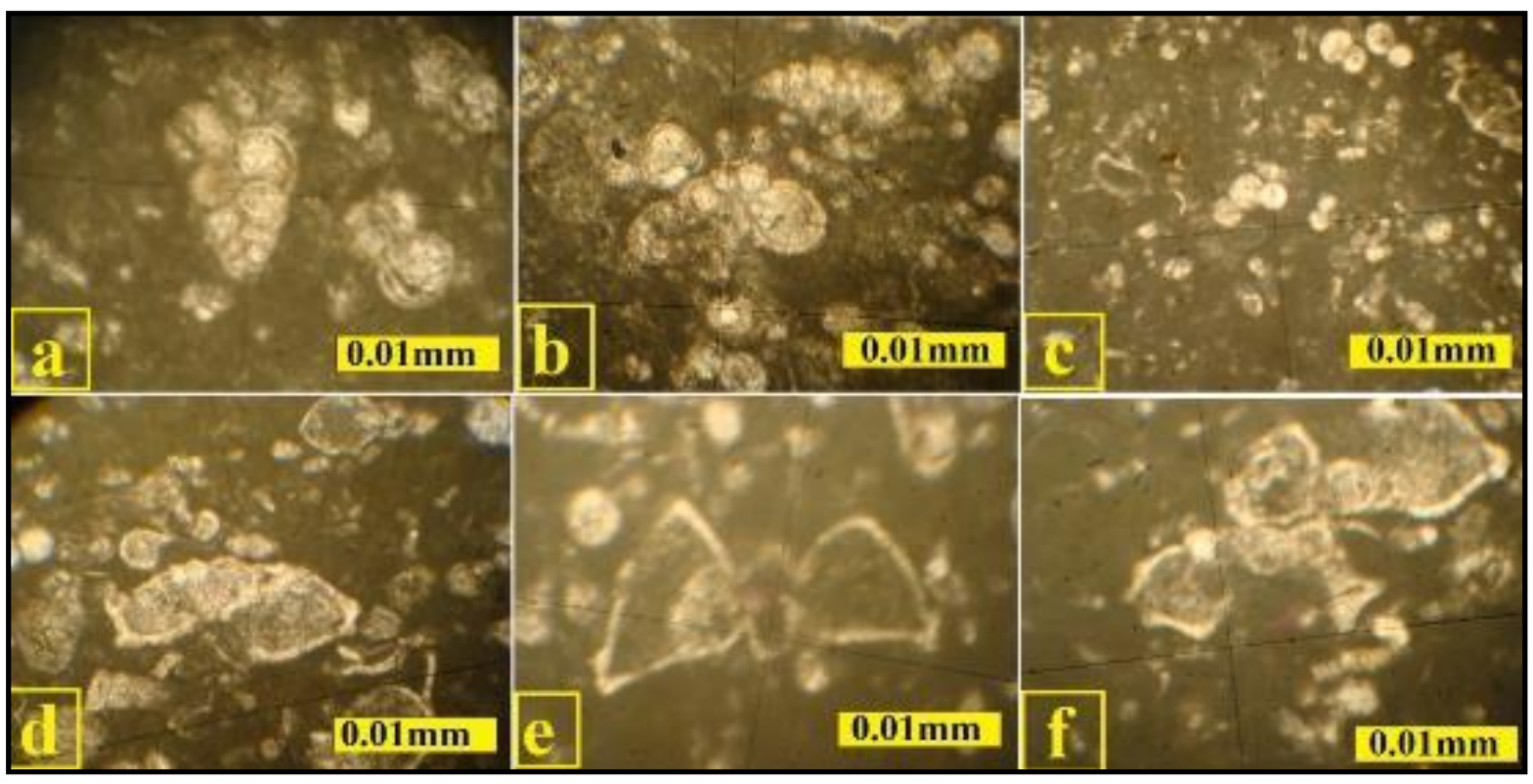

Fig. 3. a. Heterohelix reussi; b-Whiteinenella archaeocretacea; c-Archaeoglobigerina blowi; dDicarinella primitive; e-Dicarinella concavata; f-Marginotruncana coronata 


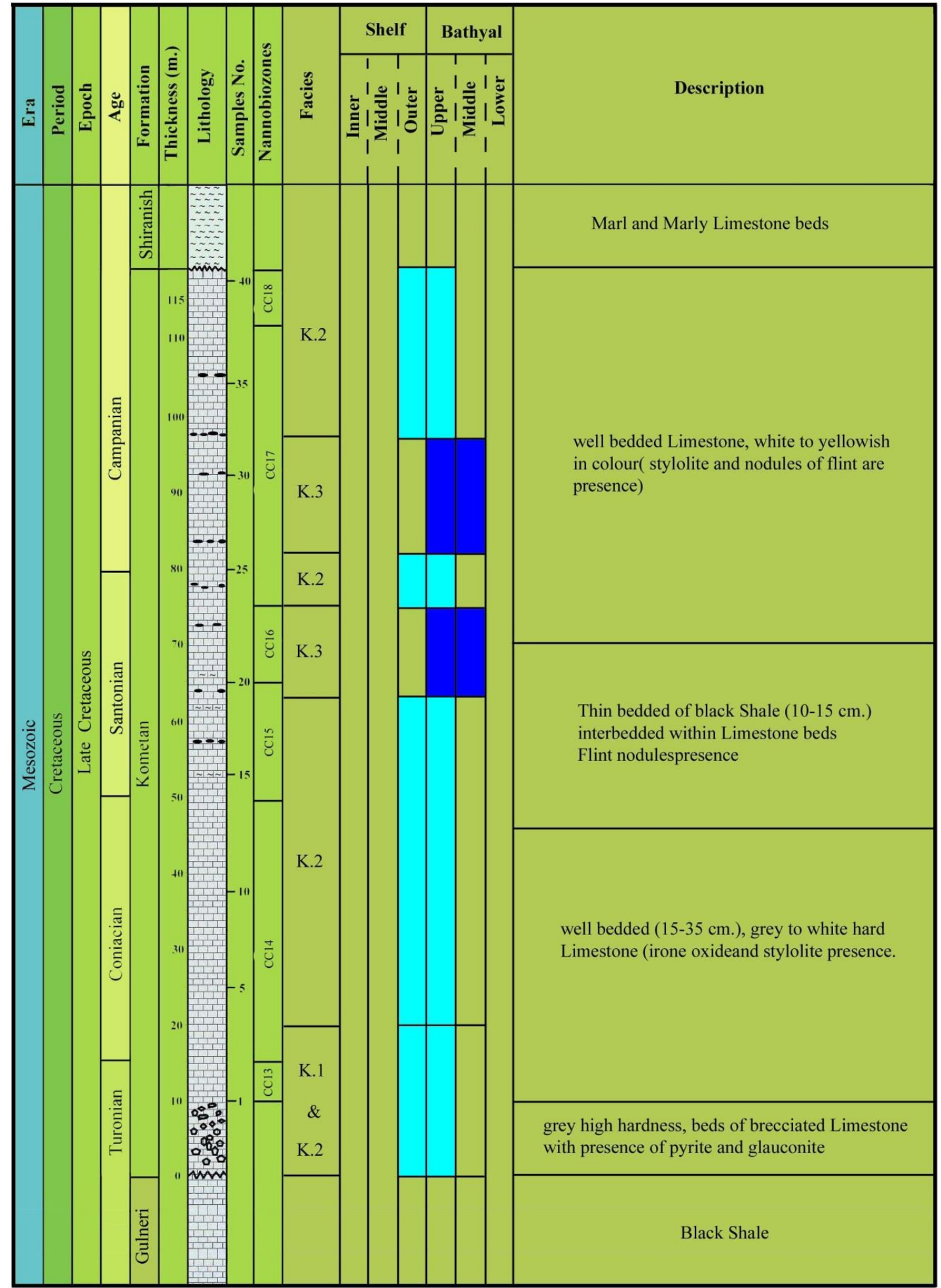

Fig. 4. Lithological description and microfacies distribution of Kometan Formation in Dokan section

\subsection{Calcareous Nannofossils}

Kingdom Protista

Division Chrysophyta

Class Coccolithophyceae 


\subsubsection{Heterococcolith}

Family Chistozygaceae Rood, Hay and Barnard, 1973

Genus Chiastozygus Gartner, 1968

Chiastozygus sp.(Pl.1,Fig.1)

Genus Gorkaea Varol and Girgis, 1994

Gorkaea obliqueclausus (Varol, 1991) Varol and Girgis, 1994 (Pl.1,Fig.2)

Genus Reinhardtites Perch- Nielsen, 1968

Reinhardtites anthophorus (Deflandre, 1959) Perch-Nielsen, 1968 (Pl.1,Fig.3)

Reinhardtitus sp.(Pl.1,Fig.4)

Genus Zeugrhabdotus Reinhardt, 1965

Zeugrhabdotus embergeri (Noël, 1959) Perch-Nielsen, 1984(Pl.1,Fig.5)

Zeugrhabdotus sigmoides (Bramlette \& Martini, 1964) Bown \& Young, 1997 (Pl.1,Fig.6)

Family Eiffellithaceae Reinhardt, 1965

Genus Eiffellithus Reinhardt, 1965

Eiffellithus eximius (Stover, 1966) Perch-Nielsen, 1968 (Pl.1,Fig.7)

Eiffellithus gorkae Reinhardt, 1965(Pl.1,Fig.8)

Eiffellithus parvus Watkins \& Bergen, 2003(Pl.1,Fig.9)

Eiffellithus turriseiffelii (Deflandre \& Fert, 1954) Reinhardt, 1965 (Pl.1,Fig.10)

Family Ellipsagelosphaeraceae Noel, 1965

Genus Cyclagelosphaera Noel, 1965

Cyclagelosphaera argoensis Bown, 1992(Pl.1,Fig.11)

Genus Ellipsageolosphaera Noel, 1965

Ellipsageolosphaera britannica (Stradner, 1963) Perch-Nielsen, 1968(Pl.1,Fig.12)

Family Cretarhabdaceae Thierstein, 1973

Genus Retecapsa Black, 1971

Retecapsa angustiforata Black, 1971(Pl.1,Fig.13)

Retecapsa crenulata (Bramlette \& Martini, 1964) Grün and Allemann, 1975 (Pl.1,Fig.14)

Family Watznaueriaceae Rood et al., 1971

Genus Watznauria Reinhardt, 1964

Watznaueria barnesiae (Black \& Barnes, 1959) Perch-Nielsen, 1968(Pl.1,Fig.15)

Watznaueria biporta Bukry, 1969(Pl.1,Fig.16)

Watznauriasp.(Pl.1,Fig.17)

Family Arkhangelskiellaceae Bukry, 1969 emend Bown and Hampton, 1997 in Bown and Young, 1997

Genus Broinsonia Bukry, 1969

Broinsonia parca(Stradner, 1963) Bukry, 1969(Pl.1,Fig.18)

\subsubsection{Holococcolith}

Family Calyptrosphaeraceae Boudreaux and Hay, 1969 
Genus Calculites Sissingh, 1977

Calculites obscurus (Deflandre, 1959) Prins \& Sissingh in Sissingh, 1977(Pl.1,Fig.19)

Calculites cf. ovalis(Stradner, 1963) Prins \&Sissingh in Sissingh, 1977(Pl.1,Fig.20)

Calculites sp.(Pl.1,Fig.21)

Genus Lucianorhabdus Deflandre, 1959

Lucianorhabdus cayeuxii Deflandre, 1959(Pl.1,Fig.22)

Genus Russellia Risatti, 1973

Russellia bukryi Risatti, 1973(P1.2,Fig.1)

Russellia sp.(Pl.2,Fig.2)

\subsubsection{Nannolith}

Family Microrhabdulaceae Deflandre, 1963

Genus Lithraphidites Deflandre, 1963

Lithraphidites acutus Verbeek \& Manivit in Manivit et al., 1977(Pl.2,Fig.3)

Lithraphidites serratus Shumenko 1970(Pl.2,Fig.4)

Lithraphidites sp.(P1.2,Fig.5)

Genus Microrhabdulus Deflandre, 1959

Microrhabdulus cf. decorates Deflandre, 1959 (P1.2,Fig.6),

Family Polycyclolithaceae Forchheimer, 1972

Genus Eprolithus Stover, 1966

Eprolithus cf. antiquus Perch-Nielsen, 1979(Pl.2,Fig.7)

Eprolithus floralis (Stradner, 1962) Stover, 1966(Pl.2,Fig.8)

Eprolithus sp.(Pl.2,Fig.9)

Genus Lithastrinus Stradner, 1962

Lithastrinus grillii Stradner, 1962(P1.2,Fig.10)

Lithastrinus septenarius Forchheimer, 1972(Pl.2,Fig.11)

Lithastrinus sp.(Pl.2,Fig.12)

Genus Marthasterites Deflandre, 1959

Marthasterites furcatus (Deflandre in Deflandre \& Fert, 1954) Deflandre, 1959(Pl.2,Fig.13)

Genus Micula Vekshina, 1959

Micula staurophora (Gardet, 1955) Stradner, 1963(Pl.2,Fig.14)

Micula swastika Stradner \& Steinmetz, 1984(Pl.2,Fig.15)

Genus Quadrum Manivit et al., 1977

Quadrum sp.(P1.2,Fig.16),

Genus Radiolithus Stover, 1966

Radiolithus planus Stover, 1966 (Pl.2,Fig.17)

Radiolithus sp.(Pl.2,Fig.18)

Genus Ceratolithoides Bramlette and Martini, 1964 
Ceratolithoides aculeus(Stradner, 1961) Prins \& Sissingh in Sissingh, 1977(Pl.2,Fig.19), Ceratolithoides prominens Burnett, 1997(Pl.2,Fig.20)

Ceratolithoides sesquipedalis Burnett, 1997(P1.2,Fig.21)

Ceratolithoides sp.(P1.2,Fig.22)

Plate 1

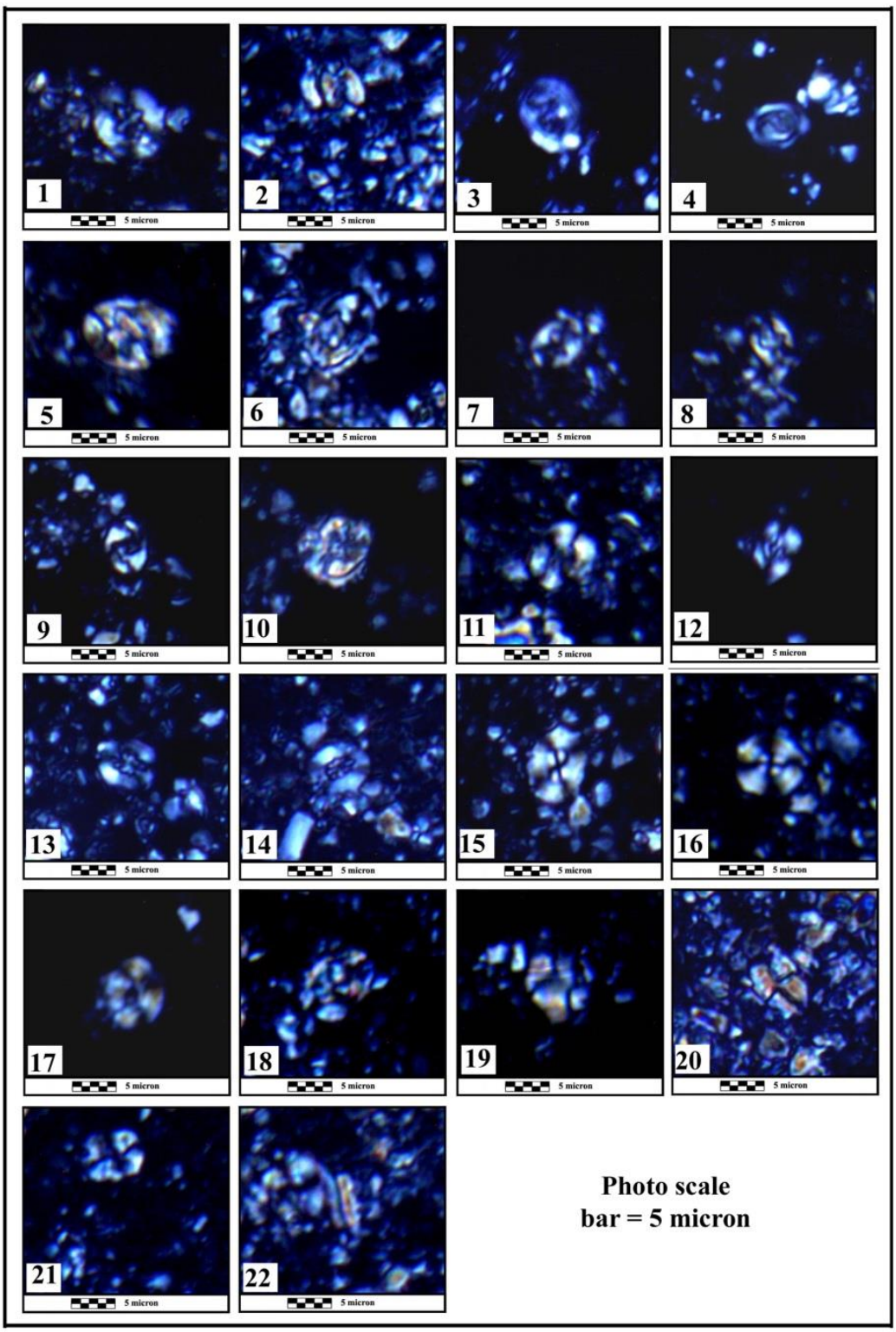

Plate 1. Nano fossils

1 - Chiastozygus sp.

2- Gorkaea obliqueclausus (Varol, 1991) Varol and Girgis, 1994

3 - Reinhardtites anthophorus (Deflandre, 1959) Perch-Nielsen, 1968

4 - Reinhardtitus sp.

5 -Zeugrhabdotus embergeri (Noël, 1959) Perch-Nielsen, 1984

6-Zeugrhabdotus sigmoides (Bramlette\& Martini, 1964) Bown\& Young, 1997

7 - Eiffellithus eximius (Stover, 1966) Perch-Nielsen, 1968

8 - Eiffellithus gorkae Reinhardt, 1965 
9 -Eiffellithus parvus Watkins\& Bergen, 2003

10 - Eiffellithus turriseiffelii (Deflandre in Deflandre\&Fert, 1954) Reinhardt, 1965

11 -Cyclagelosphaera argoensisBown, 1992

12 - Ellipsageolosphaera britannica (Stradner, 1963) Perch-Nielsen, 1968

13 - Retecapsa angustiforata Black, 1971

14 - Retecapsa crenulata (Bramlette\& Martini, 1964) Grün in Grün and Allemann, 1975

15 -Watznaueria barnesiae (Black in Black \& Barnes, 1959) Perch-Nielsen, 1968

16 -Watznaueria biporta Bukry, 1969

17 -Watznauria sp.

18 - Broinsonia parca (Stradner, 1963) Bukry, 1969

19 - Calculites obscurus (Deflandre, 1959) Prins\&Sissingh in Sissingh, 1977

20 -Calculites cf. ovalis (Stradner, 1963) Prins\&Sissingh in Sissingh, 1977

21 - Calculites sp.

22 - Lucianorhabdus cayeuxii Deflandre, 1959

Plate 2

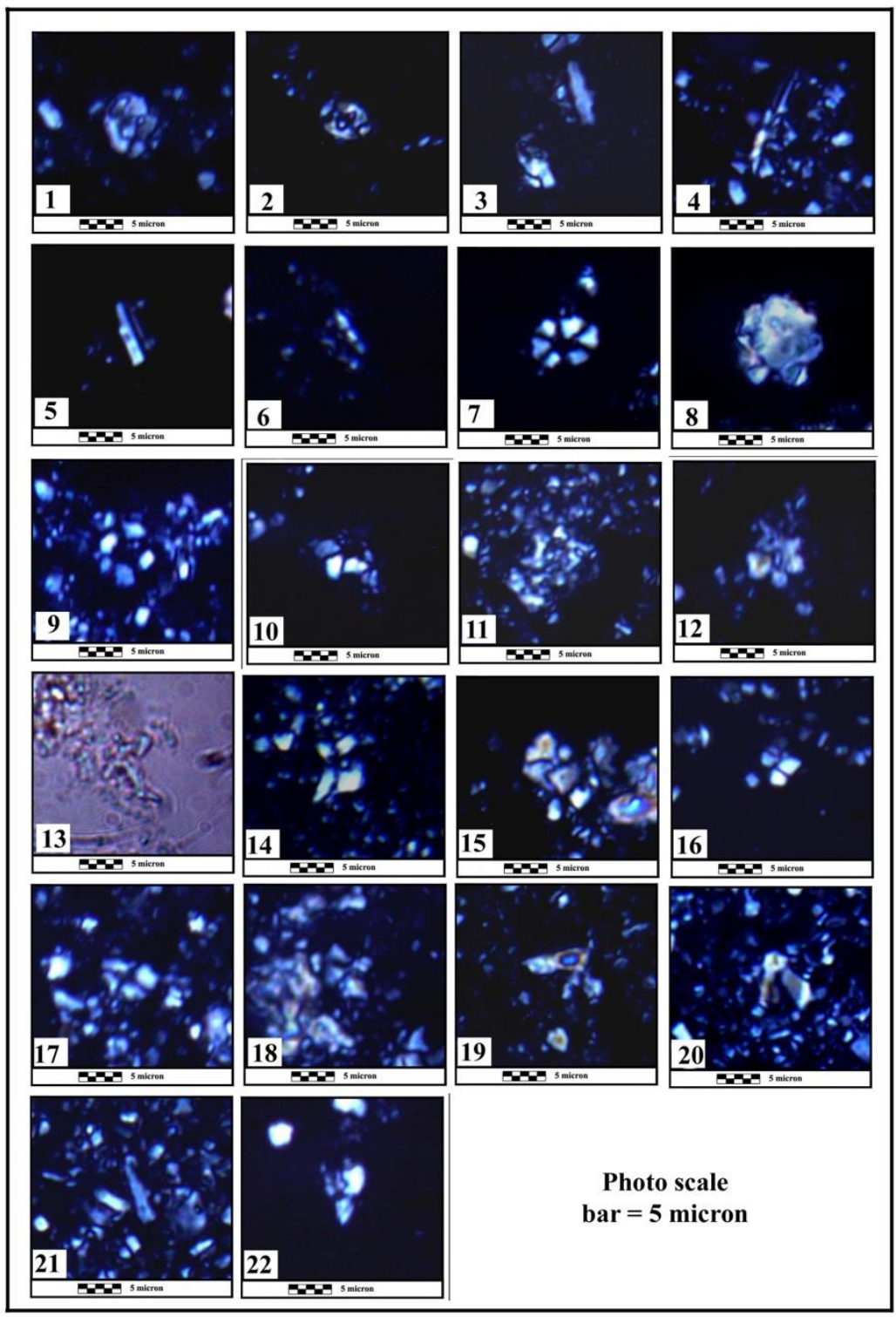

Plate 2. Nano fossils 
1 - Russellia bukryi Risatti, 1973

2 - Russellia sp.

3 - Lithraphidites acutus Verbeek \& Manivit in Manivitet al., 1977

4 - Lithraphidites serratus Shumenko 1970

5 - Lithraphidites sp.

6-Microrhabdulus cf. decorates Deflandre, 1959

7 - Eprolithus cf. antiquus Perch-Nielsen, 1979

8 - Eprolithus floralis (Stradner, 1962) Stover, 1966

9 - Eprolithus sp.

10- Lithastrinus grillii Stradner, 1962

11 - Lithastrinus septenarius Forchheimer, 1972

12 - Lithastrinussp.

13 - Marthasterites furcatus (Deflandre in Deflandre \& Fert, 1954) Deflandre, 1959

14 - Micula staurophora (Gardet, 1955) Stradner, 1963

15 - Micula swastica Stradner\& Steinmetz, 1984

16 - Quadrum sp.

17 - Radiolithus planus Stover, 1966

18 - Radiolithus sp.

19 - Ceratolithoides aculeus(Stradner, 1961) Prins \& Sissingh in Sissingh, 1977

20 - Ceratolithoides prominensBurnett, 1997

21 - Ceratolithoides sesquipedalisBurnett, 1997

22 - Ceratolithoides sp.

\section{Discussion}

\subsection{Nannobiostratigraphy}

Depending on the stratigraphic distribution of the recorded species, the five following biozones are identified (Figs. 5 and 6):

\subsubsection{Marthasterites furcatus interval zone (CC13)}

Definition: Interval from first occurrence of Marthasterites furcatus to first occurrence of Micula staurophora.

Thickness: (15) meters.

Correlation and Discussion: This biozone is correlated with the biozone (CC13) (Marthasterites furcatus Biozone) by Sissigh (1977) and correlated upper part of UC9 biozone which is studied by Burnett (1998), therefore we suggested the Late Turonian (Gradstein et al. 2012).

\subsubsection{Micula staurophora interval zone (CC14)}

Definition: Interval from first occurrence of Micula staurophorato first occurrence of Reinhardites anthophorus.

Thickness: (35) meters.

Correlation and Discussion: This biozone is correlated with the biozone (CC14) (Marthasterites decussate Biozone) by Sissigh (1977) and correlated with UC10biozone which is studied by Burnett (1998) therefore we suggested the Coniacian (Gradstein et al. 2012).

\subsubsection{Reinhardites anthophorus interval zone (CC15)}

Definition: Interval from first occurrence of Reinhardites anthophorus to first occurrence of Lucianorhabdus cayeuxii.

Thickness: (15) meters. 
Correlation and Discussion: This biozone is correlated with the biozone (CC15) (Reinhardites anthophorus Biozone) by Sissigh (1977) and correlated upper part of UC10 and lower part of UC 11 biozones which is studied by Burnett (1998) therefore we suggested the Early Santonian (Gradstein et al. 2012).

\section{1.4. Lucianorhabdus cayeuxii interval zone (CC16)}

Definition: Interval from first occurrence of Lucianorhabdus cayeuxii to first occurrence ofCalculites obscurus.

Thickness: (10) meters.

Correlation and Discussion: This biozone is correlated with the biozone (CC16) (Lucianorhabdus cayeuxii Biozone) by Sissigh (1977) and correlated lower part of UC 11 and upper part of UC 12biozones which is studied by Burnett (1998) therefore we suggested the Middle to Late Santonian (Gradstein et al. 2012).

\subsubsection{Calculites obscurus interval zone (CC17)}

Definition: Interval from first occurrence of Calculites obscurusto first occurrence of Brosonia parca.

Thickness: (35) meters.

Correlation and Discussion: This biozone is correlated with the biozone (CC17) (Calculites obscurus Biozone) by Sissigh (1977) and correlated upper part of UC 12 and lower part of UC 13biozones which is studied by Burnett (1998) therefore we suggested the Early Campanian (Gradstein et al. 2012).

\subsubsection{Brosonia parca interval zone (CC18)}

Definition: Interval from first occurrence of Brosonia parca to last occurrence of Marthastrites furcatus.

Thickness: (10) meters

Correlation and Discussion: This biozone is correlated with the biozone (CC18) (Brosonia parca Biozone) by Sissigh (1977) and correlated of UC 14 biozone which is studied by Burnett (1998) therefore we suggested the Early Campanian (Gradstein et al. 2012).

\subsection{Depositional Environment}

Depending on the field data and the results of the microfacies analysis of the Kometan Formation rocks, it was found that there are three basic microfacies that, with their fossils evidence, reflected the environmental conditions and the ancient sedimentary environment of the formation. Three microfacies were diagnosed throughout the entire formation rocks: lime mudstone (k.1), planktonic foraminiferal lime wackestone-packstone (k.2), and keeled planktic foraminiferal lime wackestone / packstone microfacies (k.3). The appearance of these microfacies varies within the study section, where the deposition of a Kometan Formation is initiated directly by the lime mudstone and planktonic foraminiferal lime wackestone-packstone microfacies which occupies the lower part of the formation. These microfacies were characterized by the abundance of fossils of planktic foraminifera, whose presence indicates a deep marine environment. Due to the wide range of percentages of planktonic foraminifera present in the sediments of the Kometan formation, their environmental significance varies according to the ranges mentioned by (Gibson, 1989). This researcher confirmed that the facies in which the planktic foraminifera reaches more than $(70 \%)$ of the total skeletal grains indicates the environment of the upper bathyal zone, while the percentage less than (50\%) indicate the outer shelf environment. Thus, it becomes clear that these sequences of Kometan formation deposits in the outer shelf - upper bathyal environment. 


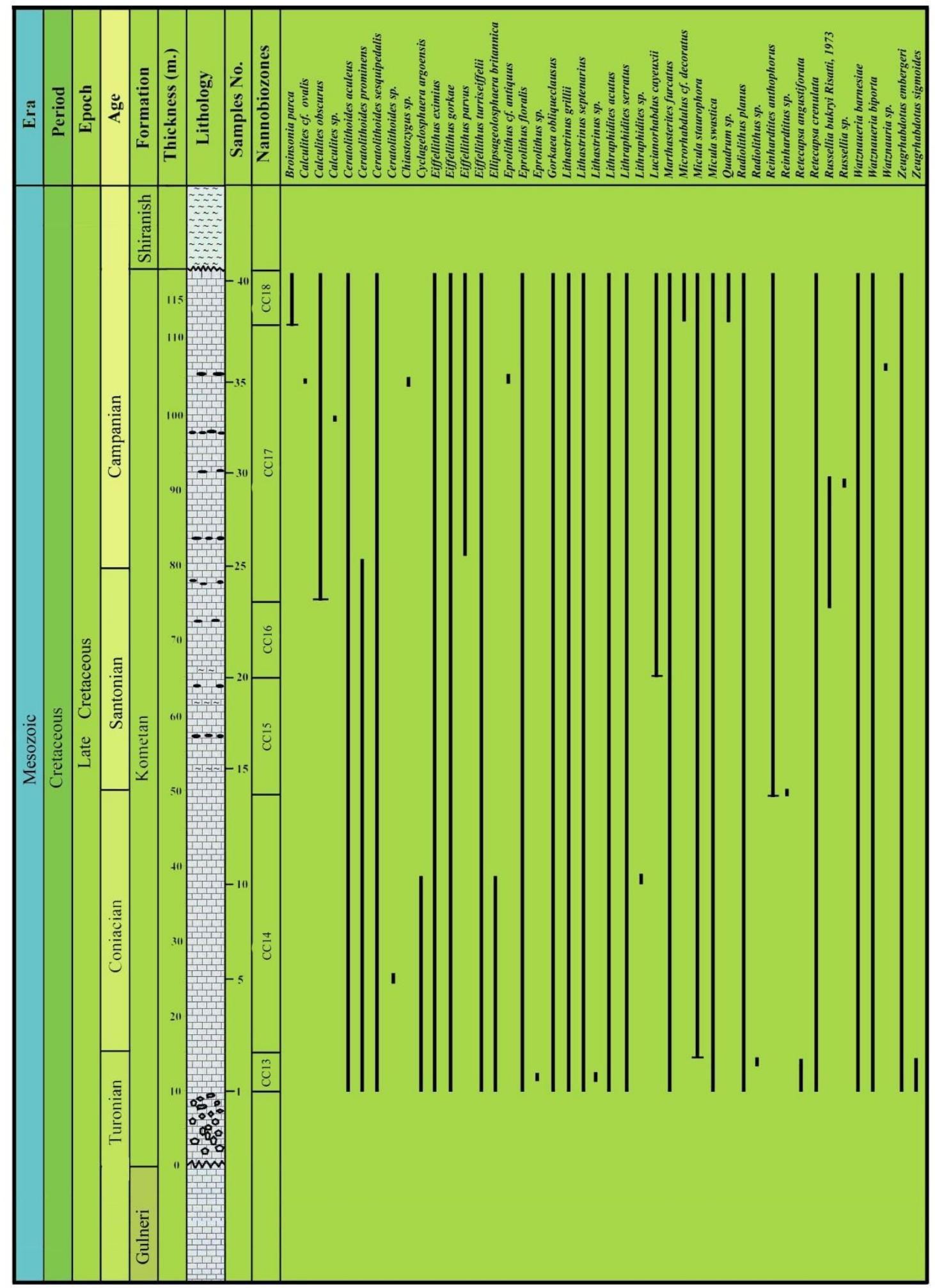

Fig. 5. Calcareous nannofossils biozones of studied section 


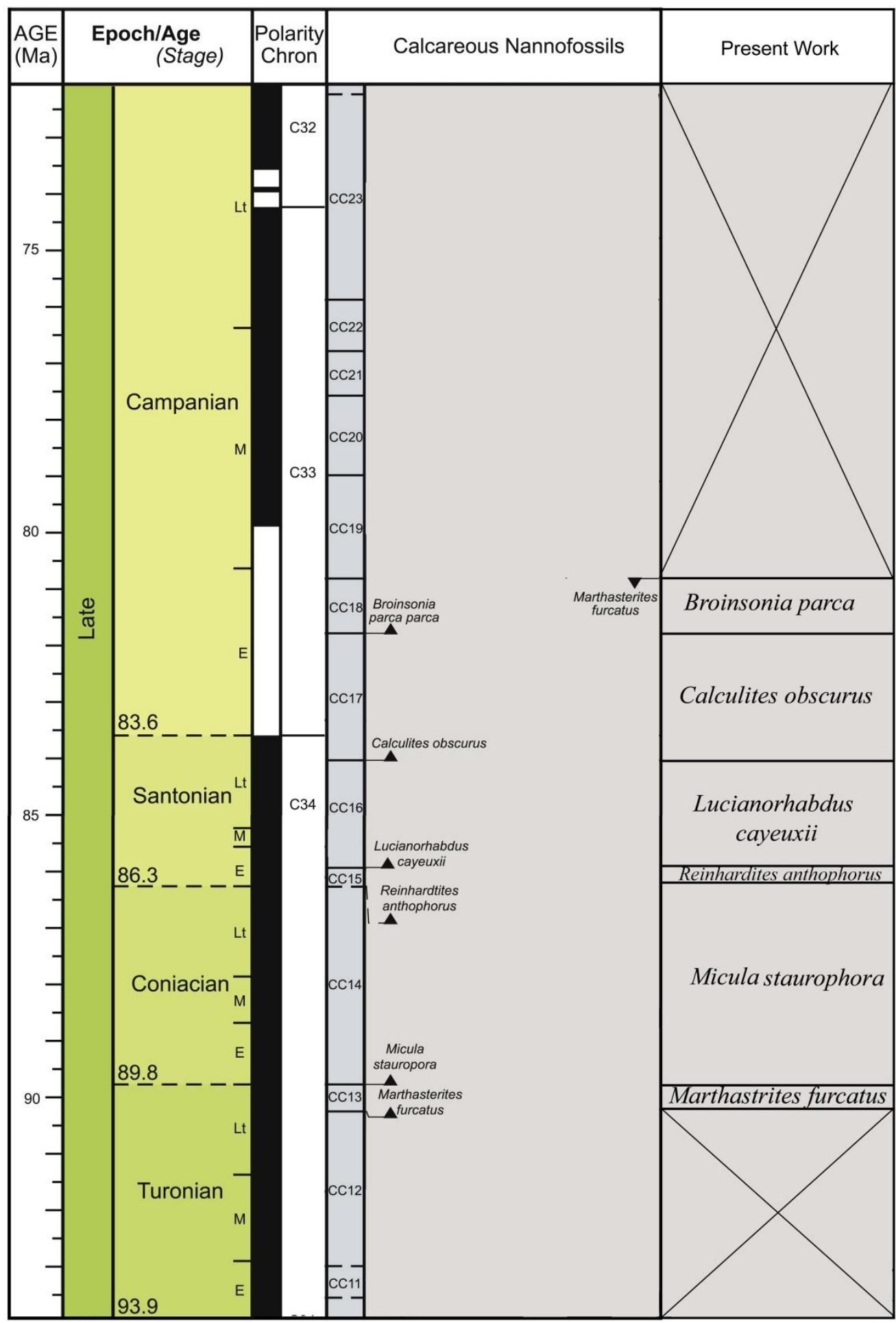

Fig. 6. Correlation chart of calcareous nannofossils biozones of studied section

The presence of the genus Globigerinelloides and Heterohelix in this microfacies, as well as the scarcity of the benthonic foraminifera and the increased burden of mechanical and chemical compression processes, were evidence of its deposition in the relatively deep marine environment far from the effects of waves and ocean currents in which the depth ranges from 200-600m usually spread within the upper bathyal, with the possibility of extending to the outer shelf (Freidman and Reekman, 
1982; Berggren and Miller 1989).This microfacies corresponds to the standard microfacies (SMF8) located within the (FZ2) zone known as open marine environments within the outer shelf and upper slope according to the Wilson (1975) or the range of the deep shelf according to the Flügel (2004).The previous microfacies were followed by deposition of a keeled planktic foraminifera lime wackestone -packstone microfacies (k.3) at the middle part of the formation, which was characteristic of the common of the planktonic foraminiferal species that owns the keeled as (Dicarinella primitive , Dicarinella imbricata, Dicarinella concavata, Dicarinella hagni, Marginotruncana renzi, Marginotruncana sigali, Marginotruncana marginata, Marginotruncana coronate ). The spread of these species within this section is evidence of deep marine environments within the slope (outer shelf to upper-middle bathyal environments with water depth 150-1500m. (Leckie 1987; Koutsoukos and Hart 1990; Hibrecht et al. 1992; Ameen and Gharib, 2014; Jaff and al khatany, 2020). The upper succession of the formation is characterized by the re-emergence of the planktonic foraminiferal lime wackestone-packstone (k.2) with an indication of the presence of a marine tyranny that may be local in the middle parts of this succession represented by the emergence of a keeled planktonic foraminiferal lime wackestone/ packstone (k.3). The appearance of the microfacies type (K. 2) at the top of the formation, which is characterized by its containment of the genus (Archaeoglobigerina blowi), refers to deposition in rather shallow sedimentary environments.

The noticeable increase in the spread of stylolite and the micritic matrix with common of iron oxides within the Kometan's limestones through whole studied section refers to a deep marine environment with reducing conditions, low oxygen at the deposition environment (Kauffman and Sageman, 1990) on the other hand, the abundance of planktonic foraminifera, as well as the scarcity of the benthonic foraminifera, indicates the occurrence of sedimentary processes in a pelagic environment whose depths are limited to (200-1500) meters. It is exemplified by the two bathyal zones: the upper and the middle bathyal. As it was clearly evident, such properties are common features of Kometan Formation in the study area.

\section{Conclusions}

The Kometan Formation in Dokan dam section (North Iraq) consists of limestone and dolomitic limestone, which have cherts nodules throughout the formation. The lower and upper contacts with the Gulneri and Shiranish formations respectively appeared unconformably. Three microfacies are identified refers that the sedimentary environment of the formation is the outer shelf - upper bathyal to middle bathyal. The Kometan Formation age is Late Turonian -Early Campanian on the basis of stratigraphic ranges of the recorded calcareous nannofossils biozones that arranged from oldest to youngest as follows:

- MarthasteritesfurcatusIntervalZone (CC13)

- Miculastaurophora Interval Zone (CC14)

- Reinharditesanthophorus Interval Zone (CC15)

- Lucianorhabduscayeuxii Interval Zone (CC16)

- Calculitesobscurus Interval Zone (CC17)

\section{Acknowledgements}

The authors are very grateful to the College of Science, University of Mosul for their provided facilities, which helped to improve the quality of this work. The authors are very grateful to the Editor in Chief Prof. Dr. Salih M. Awadh, the Secretary of Journal Mr. Samir R. Hijab. and the Technical Editors for their great efforts and valuable comments. 


\section{References}

Abawi, T. S., Hammoudi, R. A., 1997. Foraminiferal biostratigraphy of the Kometan and Gulneri formations (Upper Cretaceous) in Kirkuk area, North of Iraq. Iraqi Geological Journal, 30(2),139-146.

Al-Jassim, J.A., Al-Sheikhly, S. S. J., Al-Tememmey, F.M., 1989. Biostratigraphy of the Kometan Formation (Late Turonian - Early Campanian) in Northern Iraq. Journal Geological Society, Iraq, 22 (1), 53-60.

Al-Khafaf, A.O., 2005. Stratigraphy of Kometan Formation (Upper Cretaceous) in Dokan-Endezah Area, NE Iraq. Unpub. M.Sc. Thesis, University of Mosul, 79pp.

Ameen, F. A., and Gharaib, H. 2014. Biostratigraphy of the Tethyan cretaceous successions from northwestern Zagros fold-thrust belt, Kurdistan region, NE Iraq. Arabian Journal of Geosciences, 7(7), 2689-2710.

Bellen, R.C. van, Dunnington, H.V., Wetzel, R. and Morton, D., (1959). Lexique Stratigraphique International. Asie, Iraq, Fasc. 10a, Paris, 333pp.

Berggren, W. A., Miller, K. G. 1989. Cenozoic bathyal and abyssal calcareous benthic foraminiferal zonation. Micropalentology, 35(4), 308-320.

Black, M., Barnes, B., 1959.The structure of Coccoliths from the English Chalk. Geological Magazine. 96 (5), 321-328.

Black, M., 1971. Coccoliths of the Speeton Clay and Sutter by Marl. Proceedings of the Yorkshire Geological Society.38, 381-424.

Bown, P. R., 1992. New calcareous nannofossil taxa from the Jurassic-Cretaceous boundary interval of Sites 765 and 261, Argo Abyssal Plain.Proceedings of the Ocean Drilling Program, Scientific Results. 123, 369-379.

Bown, P. R., Young, J. R., 1997. Mesozoic calcareous nannoplankton classification. Journal of Nannoplankton Research, 19(1), 21-36.

Bramlette, M. N., Martini, E., 1964. The great change in calcareous nannoplankton fossils between the Maastrichtian and Danian. Micropaleontology,10(2), 291-322.

Buday, T., 1980. The Regional Geology of Iraq, Vol.1: Stratigraphy and Paleogeography. I.I.M Kassab and S.Z. Jassim (Eds.), GEOSURV, Baghdad, Iraq, 445pp.

Bukry, D., 1969. Upper Cretaceous coccoliths from Texas and Europe. University of Kansas Paleontological Contributions, 51(2), 1-79.

Burnett, J. A., 1997. New species and conjectured evolutionary trends of CeratolithoidesBramlette and Martini, 1964 from the Campanian and Maastrichtian of the Indian Ocean. Journal of Nannoplankton Research, 19(2), 123-131.

Carver, R. E., 1971. Procedures in Sedimentary Petrology, John Wiley, New York, 653 pp.

Deflandre, G., Fert, C., 1954. Observations sur les coccolithophorid ésactuelset fossilesenmicroscopieordinaireetélectronique. Annales de Paléontologie, 40, 115-176.

Deflandre, G., 1959. Sur les nannofossilescalcairesetleursystématique.Revue de Micropaléontologie, 2, 127-152.

Dunham, R. H., 1962. Classification of carbonate rocks according to depositional texture. In: Ham WE (ed.) Classification of carbonate rocks. American Association of Petroleum Geologist, 1, 108-121

Forchheimer, S., 1972. Scanning electron microscope studies of Cretaceous coccoliths from the Köpingsberg Borehole No. 1, SE Sweden. SverigesGeologiskaUndersökning, 65, 1-141.

Flugel, E., 2004. Microfacies of Carbonate Rocks: Analysis, Interpretation and Application. Springer, Berlin, 976 pp.

Friedman, G. M., Reeckman, A., 1982. Exploration for Carbonate Petroleum Reservoirs, Elf- Equitatine Centers de Recherche de Boussenset et de pau, John Wiely and Sons. New York, 213 pp.

Gardet, M., 1955. Contribution à l'étude des coccolithes des terrains néogènes de l'Algérie.Publications du Service de la Carte Géologique de l'Algérie (Nouvelle Série), 5, 477-550.

Gibson, T. G., 1989. Planktonic benthonic foraminiferal ratios: Modern patterns and Tertiary Applicability, Journal Marine Micro-paleontology, 15, 29-52.

Grün, W., Allemann, F., 1975. The Lower Cretaceous of Caravaca (Spain): Berriasian Calcareous Nannoplankton of the Miravetes Section (Subbetic Zone, Prov. of Murcia). Eclogae Geologicae Helvetiae, 68, 147-211.

Hilbercht, H., Hubberten, H., Oberhansli, H., 1992. Biogeography of Planktonic foraminifera and regional carbon isotops Variation Productivity and Water Masses in Late Cretaceous Europe. Palaeogeography, Palaeoclimate, Palaeoecology, 92, 407-421. 
Jaff, R. B. N., Williams, M., Wilkinson, I. P., Lawa, F., Lee, S., Zalasiewicz, J., 2014. A refined foraminiferal biostratigraphy for the Late Campanian-Early Maastrichtian succession of northeast Iraq. GeoArabia, 19 (1), 161-180.

Jaff, R. B. N., Wilkinson, I. P., Lee, S., Zalasiewicz, J., Lawa, F., Williams, M., 2015. Biostratigraphy and palaeoceanography of the early Turonian-early Maastrichtian planktic foraminifera of northeast Iraq. Journal of Micropalaeontology, 34 (2), 105-138.

Jaff R. B. N. AND Al-Khatany K. (2020) Coniacian/Santonian calcareous nannofossil and planktonic foraminifera in the Kurdistan Region, NE Iraq: biostratigraphy and bioevents .Arabian Journal of Geosciences, 13 (18), 1-12

Jassim, S. Z., Goff, J. C., 2006. Geology of Iraq. Czech Republic, Dolin, Prague and Moravian Museum, Brno, $341 \mathrm{pp}$.

Karim, K. H., Lawa, F. A., Ameen, B. M., 2001. Upper Cretaceous Glauconite filled boring from Dokan area, Kurdistan Region (NE Iraq), Kurdistan Academician Journal, 1, (1), A.

Karim, K. H., Khalid, M. I., Bakhtiar, M. A., 2008. Lithostratigraphic study of the contact between Kometan and Shiranish Formations (Cretaceous) from Sulaimaniyah Governorate, Kurdistan Region, NE Iraq. Iraqi Bulletin of Geology and Mining, 4(2), 16-27

Kauffman, E. G., Sageman, B. B., (1990). Biological sensing of benthic environments in dark shales and related oxygen - restricted facies. In: Ginsburg, R.N. and Beaudoin, B., eds., Cretaceous resources, events and rhythms background and plans for research. Kluwer Academic publishers. London. 352 pp.

Koutsoukos, E. A., Hart, M. B., 1990. Cretaceous foraminiferal morpho groups distribution Pattern, Paleocommunities and Trophic Structure. A Case Study from Sergipe Basin, Brazil. Transaction of the Royal Society of Edinbeurgh. Earth Science, 81, 221-246.

Lawa, F.A., Koyi, H., Ibrahim, A., 2013. Tectono-stratigraphic evolution of the NW segment of the Zagros Fold-Thrust Belt, Kurdistan, NE-Iraq. Journal of Petroleum Geology, 36 (1), 75-96.

Lawa, F.A., 2018. Late Campanian-Maastrichtian sequence stratigraphy from Kurdistan foreland basin, NE Iraq. Journal of Petroleum Exploration and Production Technology, 8,713-732.

Leckie, R. M., 1987. Paleoecology of Mid-Cretaceous planktonic foraminifera; a comparison of open ocean and epicontinental sea assemblages. Micropaleontology, 33 (2), 164-176.

Malak, Z. A., 2015. Sequence stratigraphy of Shiranish Formation in Dokan area, Northern Iraq. Arabian Journal Geoscience, 8, 9489-9499.

Manivit, H., Perch-Nielsen, K., Prins, B., Verbeek, J. W., 1977. Mid Cretaceous calcareous nannofossil biostratigraphy. Proceedings of the Koninklijke Nederlandse Akademie van Wetenschappen, 80(3), 169-181.

Noël, D., 1959. Étude de coccolithes du Jurassiqueet du Crétacéinférieur. Publications du Service de la Carte Géologique de l'Algérie (Nouvelle Série) Bulletin, 20, 155-196.

Numan, N. M. S., 2001. Cretaceous and Tertiary Alpine subductional history in Northern Iraq. Iraqi Journal of Earth Sciences, 12, 59-74.

Omar, A. A., Lawa, F. A., Sulaiman, S. H., 2015. Tectonostratigraphic and structural imprints from balanced sections across the north-western Zagros fold-thrust belt, Kurdistan region, NE Iraq. Arabian Journal of Geosciences, 8(10), 8107-81.

Perch-Nielsen, K., 1968. Der Feinbau und die Klassifikation der CoccolithenausdemMaastrichtien von Danemark. BiologiskeSkrifter, Kongelige Danske VidenskabernesSelskab, 16, 1-96.

Perch-Nielsen, K., 1979. Calcareous nannofossils from the Cretaceous between the North Sea and the Mediterranean. Aspekte der Kreide Europas, IUGS Series, 6, 223-272.

Perch-Nielsen, K., 1984. Validation of new combinations. INA Newsletter, 6(1), 42-46.

Reinhardt, P., 1965. NeueFamilienfürfossileKalkflagellaten (Coccolithophoriden, Coccolithineen). Monatsberichte der DeutschenAkademie der Wissenschaftenzu Berlin, 7, 30-40.

Reinhardt, P., 1967. Fossil Coccolithenmitrhagoidem Zentralfeld (Fam. Ahmuellerellaceae, Subord.Coccolithineae). NeuesJahrbuchfürGeologie und Paläontologie, Monatshefte, 1967, 163-178.

Risatti, J. B., 1973. Nannoplankton biostratigraphy of the Upper Bluffport Marl-Lower Prairie Bluff Chalk interval (upper Cretaceous) in Mississippi.In, Smith, L. A., Hardenbol, J. (eds) Proceedings of the Symposium on Calcareous Nannofossils. Gulf Coast Section SEPM Publication, 8-57. 
Sharland, P. R., Archer, R., Casey, D. M., Davies, R. B., Hall, S. H., Heward, A. P., Horbury, A. D., Simmons, M. D., 2001. Arabian plate sequence stratigraphy, GeoArabia, Special publication 2, Gulf Petro Link, Bahrain, $372 \mathrm{pp}$.

Shumenko, S. I., 1970. An electron microscopic study of Microrhabdulids and their taxonomic position. Paleontology cheskiy Zhurnal, 4(2), 18-23.

Sissingh, W., 1977. Biostratigraphy of Cretaceous calcareous nannoplankton.GeologieenMijnbouw, 65(1), 37-65.

Stover, L. E., 1966. Cretaceous coccoliths and associated nannofossils from France and the Netherlands.Micropaleontology, 12(2), 133-167.

Stradner, H., 1961. Vorkommen von Nannofossilienim Mesozoikum und Alttertiär.Erdoel-Zeitschrift, 77(3), $77-88$.

Stradner, H., 1962. Überneue und wenigbekannteNannofossilienausKreide und Alttertiär.Verhandlungen der GeologischenBundesanstalt (Wien), 2, 363-377.

Stradner, H., 1963. New contributions to Mesozoic stratigraphy by mean of nannofossils. Proceedings of the Sixth World Petroleum Congress. Section 1, 4, 167-183.

Stradner, H., Steinmetz, J., 1984. Cretaceous calcareous nannofossils from the Angola Basin, Deep Sea Drilling Project Site 530.Initial Reports of the Deep-Sea Drilling Project.75, 565-649.

Taha, Z. A., Karim, K. H., 2009. New ideas about gulneri shale formation (Early Turonian) in Dokan Area, Kurdistan Region, NE-Iraq, Iraqi Bulletin of Geology and Mining, 5 (2), 29-39.

Youkhanna, A. K., 1976. Foraminifera and biostratigraphy of some Late Cretaceous marine sediments of North -East Iraq, University of Wales (Swansea), Unpublished Ph. D. Thesis, 318 pp.

Varol, O., 1991. New Cretaceous and Tertiary Calcareous nannofossils. NeuesJahrbuchfürGeologie und Paläontologie, Abhandlungen, 182, 211-237.

Varol, O., Girgis, M., 1994. New taxa and taxonomy of some Jurassic to Cretaceous calcareous nannofossils.NeuesJahrbuchfürGeologie und Paläontologie, Abhandlungen, 192, 221-253.

Watkins, D. K., Bergen, J. A., 2003. Late Albian adaptive radiation in the calcareous nannofossil genus Eiffelithus. Micropaleontology, 49(3), 231-252.

Wilson, J. L., 1975. Carbonate facies in geologic history. Springer, Berlin. 